\title{
Role of Creative Economy on Local Economic Development
}

\author{
${ }^{*}$ Pratomo, Satrio, ${ }^{2}$ Azhar, Khusnul \& ${ }^{3}$ Satria, Dias \\ ${ }^{*}$ Kantor Pertanahan Kabupaten Balangan, Kabupaten Balangan, Indonesia \\ ${ }^{2}$ Faculty of Economic and Business, Universitas Brawijaya, Malang, Indonesia \\ ${ }^{3}$ Faculty of Economic and Business, Universitas Brawijaya, Malang, Indonesia
}

Note: * Indicates corresponding author

\begin{tabular}{|c|c|}
\hline ARTICLE DETAILS & ABSTRACT \\
\hline $\begin{array}{l}\text { Article History } \\
\text { Published Online: publisher use } \\
\text { only }\end{array}$ & $\begin{array}{l}\text { Local economic development in Indonesia is still quite minimal, } \\
\text { requiring new policies and strategies such as the creative } \\
\text { economy. This study analyzes the influence of the creative }\end{array}$ \\
\hline $\begin{array}{l}\text { Keywords } \\
\text { Creative Economy, Local Economic } \\
\text { Development, Creative Class }\end{array}$ & $\begin{array}{l}\text { economy as represented by the concentration of the creative class } \\
\text { and its supporting factors on local economic development. Using } \\
\text { panel data from Barekraf / BPS statistics for 2011-2015, the }\end{array}$ \\
\hline "Corresponding Author & results show that the concentration of the creative working class \\
\hline Email: satrio.pratomo@atrbpn.go.id & $\begin{array}{l}\text { has a significant impact on local economic development including } \\
\text { supporting factor such as proportion graduated high educated, } \\
\text { electrification ratio and internet coverage ratio. These findings } \\
\text { indicate that the creative working class can encourage the growth } \\
\text { of local economic development in a region. }\end{array}$ \\
\hline
\end{tabular}

\section{Introduction}

Local economic development (LED) in recent decades has been recognized as a key approach and strategy in development in a number of countries (Rahma, 2006). Since it was surfaced and debated in the 60s, the LED concept has continued to develop and be applied in various countries. The results obtained are proven to be able to contribute to increased income, economic competitiveness and improve the lives of the poor and create job opportunities (UN-Habitat, 2002).

There are quite a lot of LED-related programs in Indonesia. One of them is the Kawasan Pengembangan Ekonomi Terpadu (KAPET), Poverty Allocation Rural Urban Linkages (PARUL), and the Kemitraan Pengembangan Ekonomi Lokal (KPEL). But the obtained results are not in accordance with the objectives of developing program (Supriyadi R, 2007). It does have a positive impact on the economy of the area the program is running (Widjonarko, 2013).

The report of the United Nations Conference on Trade and Development (UNCTAD) 2018 shows that there is significant growth in the creative economy. In addition, this sector can contribute to sustainable development. Judging from the total global market for creative products has grown

Faculty of Economics and Business,

Brawijaya University substantially twice from $\$ 200$ billion in 2002 to $\$ 509$ billion in 2015. This development can not be separated from the contribution of developing countries rather than developed countries. The dominance of developing countries indicates a very important role in stimulating and contributing to the global creative economy.

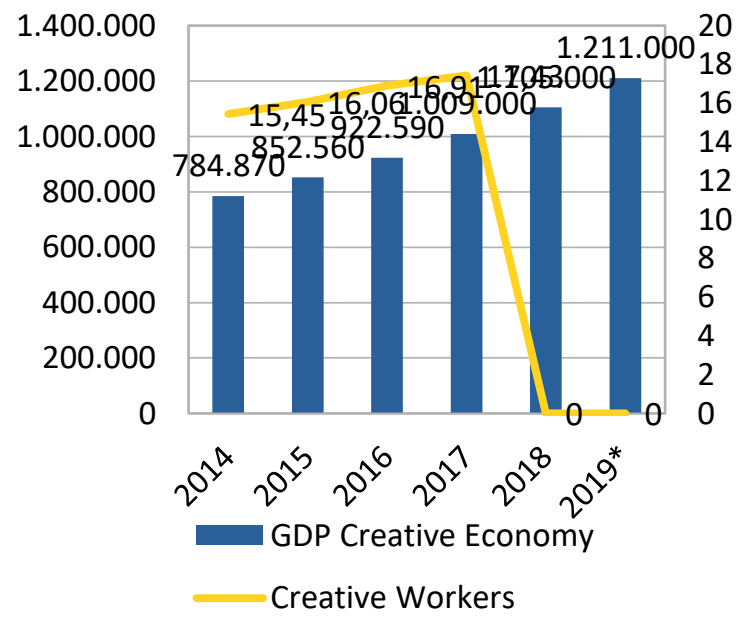

Figure 1 Indonesia Creative Economy GDP \& Workers 2014-2019*(in million)

Source: Badan Ekonomi Kreatif (2018) *estimated 
It was recorded that in 2017 the creative economy GDP was Rp. 1,009 trillion, an increase from the previous year of Rp. 922.59 trillion followed by the export value of Creative Economy GDP of $\$ 20$ billion, equivalent to $13.77 \%$ of total national exports. Apart from the GDP factor, the creative economy sector also contributes to positive employment. The number of creative economy workers until 2017 has been absorbed by 17.4 million workers, an increase from the previous year of 16.91 million (BekrafBPS, 2018).

The creative industry is considered a key sector for development and innovation. This can be seen from the influence on other industrial sectors in terms of transformation and implementation of new ideas. These conditions can accelerate the related industrial sector to develop more rapidly and increase its growth (Innocenti \& Lazzeretti, 2019). The creative industry plays a role in other industries, this is indicated by a very strong influence in increasing other industrial sectors, especially in terms of development and innovation (Bakhshi, McVittie, \& Simmie, 2008) .

Power \& Nielsén, (2011) states that the creative industry is considered a key sector for development and innovation. This can be seen from the influence on other industrial sectors in terms of transformation and implementation of new ideas. This condition can accelerate the related industrial sector to develop more rapidly and increase its growth even further.

Many creative economy research has been carried out, one of which was conducted by Ochoa \& Ramírez, (2018) which aims to build a theoretical model based on empirical findings regarding the existence of endogenous growth of spatial agglomeration consolidation in cultural and creative industries. His findings show that in Toronto there is a creative causality that transforms human capital and exploits unique synergies in increasing economic cycles. The human capital factor is the main point in the creative economy.

According Fahmi \& Koster's research, (2017) aims to identify development in the regions by looking at the contribution of Creative Economy GDP which is categorized by creative industries and cultural industries as well as the proportion of Creative Economy to other sectors. The result is that the creative industry encourages regional productivity growth which is influenced by the cultural industry. The "real" creative industry in Indonesia is not yet dominant in terms of numbers and contributions. There is a need for policies to encourage knowledgebased industries.

Faculty of Economics and Business, Brawijaya University
In the research of Zhou, He, \& Zhu, (2016) tries to identify the process of creative destruction (Creative Destruction) through the role of corporate outflows in regional industrial renewal and categorizing it as a good thing or not. The result is that companies that leave the region provide stimulation for new companies to enter the market. This is influenced by factors related to industry and institutional context. Driving factors such as privatization, globalization and decentralization create new players to enter the industry and encourage industrial renewal.

Tao, Ho, Luo, \& Sheng, (2019) tried to examine how the sources of economic agglomeration on the productivity of the creative industry $(\mathrm{Cl})$ from the local economy and the urbanized economy. The result obtained is that the effect of urbanization has a major influence on the local economy in shaping the productivity of the creative industry. In addition, communication contributes greatly to the abundance of knowledge (Knowledge Spillover) which strengthens the urbanized economy.

One of the indicators in local economic development is an increase in income for the community in an inclusive manner. So that in order to accelerate, it certainly requires new ideas and innovations that can transform so that local economic development can be achieved.

\section{Literature Review}

\section{Local Economic Development}

The LED concept focuses on mobilizing existing resources, capacities and skills that are locally owned and then used as capital in achieving quality and sustainable regional economic development. The era of regional autonomy provides fresh air for local governments to create ideal conditions that are expected as widely as possible so that LED becomes relevant to be developed. The application of LED in various countries shows an important role in stimulating economic development initiatives related to efforts to improve community welfare and reduce poverty (Rahma, 2012).

According to Rahma, (2012) there are several main principles that underlie the LED concept, including

1. Poverty and unemployment are the main challenges that must be faced so that the LED priority is to increase employment opportunities and alleviate poverty.

2. LED is targeted at disadvantaged communities in marginalized areas and communities. 
3. The LED strategy is developed in accordance with the conditions characteristic of each area.

4. LED supports local ownership, community involvement, local leadership and collective decision-making.

5. LED is built on partnerships between communities and the private and public sectors.

6. LED maximizes local resources, capabilities, skills and opportunities for mutual achievement.

7. LED provides flexibility at the local level in responding to environmental changes that occur at the local, national and international levels.

LED aims to build the economic capacity of a region to improve its economic future and the quality of life of its people. The process is carried out by public sector, business and nongovernmental partners who work collectively to create better conditions for economic growth and job creation. LED that is planned strategically is used by the community to strengthen the local economic capacity of a region, improve the investment climate, and increase the productivity and competitiveness of local businesses, employers and workers (Goga, Murphy, \& Swinburn, 2006) .

The long-term goals of the LED approach are poverty alleviation and sustainable improvement, explicitly according to Rahma, (2012) outlined in several objectives, including: (1) Accelerating economic growth through the creation of added value; (2) Creation and equal distribution of job opportunities; (3) Increasing income and improving community income distribution; (4) Increasing the competitiveness of regional economies against other regions or countries; (5) Build and develop positive cooperation between regions

\section{Creative Economy}

The term creative economy appeared on the surface when John Howkins wrote his book "Creative Economy, How People Make Money from Ideas" by defining it as an economic activity that uses creativity as input and processes it into output products that have economic value (Howkin, 2001) . However, this concept It has long been known in economics starting when Austrian economist Joseph A Schumpeter gave the idea of creative destruction in the mid-1940s. This concept focuses on the continuous process of industrial change and revolutionizes the economic structure from within. by destroying the old and creating something new (Schumpeter, 1994)

Schumpeter, (1994) developed this concept based on the thought of Karl Marx that in the end capitalism directs its own destruction by means of a creative destruction process. This is seen as going to overhaul the global economic structure. According to Schumpeter, naturally capitalism is basically a form or method of economic change and not only never but can never be stationary. The forces of fundamental change that drive and keep the capitalist machine in motion come from new consumer goods, new methods of production or transportation, new markets, new forms of industrial organization created by capitalist enterprises.

According to Schumpeter's view, the entry of innovation by entrepreneurs becomes a disruptive force that will sustain economic growth. This occurs even when it destroys the value of established firms and workers who have enjoyed a degree of monopoly power derived from the earlier technological, organizational, regulatory, and economic paradigms. This concept eventually developed and became known as the Gale of Creative Destruction.

Schumpeter's thinking led economists to explore more deeply about innovation and growth. One of them is Romer, (1997) who put forward the theory of endogenous growth. Romer argues that investment in human capital, innovation, and knowledge are significant contributors to economic growth. This theory also focuses on the positive externalities and spillover effects of a knowledge-based economy that will lead to economic development. Endogenous growth theory primarily argues that the long-run rate of growth of an economy depends on the policy steps to be taken. The policies taken are of course focused on increasing the productivity of innovation and improving the quality of human resources.

Superior quality of human resources will generate ideas and creativity. Basically, creativity is not needed in economic activity. However, it becomes necessary when generating ideas with economic implications or tradable products (Howkin, 2001). The concept of creative economy departs from new ideas that produce innovation that provides added value for growth and increases welfare (Howkin, 2001). Creativity is no longer underestimated but is the main key as raw material in the creative economy.

\section{The Role of Creative Economy in Local Economic Development}

As Palavicini-Corona, (2012) states that the definition of LED is developing but most importantly the endogenous attribute in all existing definitions. So that in understanding precisely about LED, it is necessary to

Faculty of Economics and Business, 
understand its endogenous and multidimensional properties (Pavel \& Moldovan, 2019).

Based on Goga et al., (2006) The determinants of LED are demographics (in this case human resources and human capital), local economy, local business environment, infrastructure, and regional and national policies, opportunities and competitors. Meanwhile Simms, Freshwater, \& Ward, (2014) classifies LED factors into 6 dimensions, namely Demography, Economic Structure, Income, Basic Services, spatial location and governance. The multidimensional nature of LED is also conveyed by Wong, (2002) by classifying several determinants of LED into 11 general factors, namely (a) location factors, (b) physical factors, (c) infrastructure factors, (d) human resources, (e) ) capital and finance, (f) knowledge and technology, (g) industrial structure, (h) quality of life, (i) business culture, (j) community identity and image, and (k) institutional capacity; The initial 7 factors are traditional LED factors while the last 4 factors are intangible factors.

When interpreted from the above definition of LED as a Creative Economy, it can be concluded that endogenous factors are both key in the development of economic growth. Boccella \& Salerno, (2016) from the point of view of the creative economy, significantly reflects on the necessary national and international policies that will promote deep ties between various cultural, regional and sociology-institutional networks. In an effort to provide a role for the cultural and creative sectors in the regional economy, the creative economy is positioned at the heart of the pattern of local economic development, even in underdeveloped areas. This is confirmed in the European Creative Industries Summit (2015) in Boccella \& Salerno, (2016) the development of the creative economy can be an integral part of any effort to correct inequality, provided that this process can bring about broader structural changes.

\section{Research Method}

The data used in this research is secondary data of panel data. The data was obtained from the Creative Economy Agency (Barekraf) regarding the Creative Economy Survey. The data is a collaboration between Barekraf and the Badan Pusat Statistik (BPS) in assessing creative economy actors. Then data Electrification Ratio from the Ministry of Energy and Mineral Resources and Human Development Index (HDI) data from BPS. In addition, it also uses the Kementerian Pekerjaan
Umum Statistics data for the Accessibility Ratio and the Pangkalan DIKTI for Higher Education Graduates data. This data is data covering 31 provinces in Indonesia during the period 2011 2015.

The method of analysis in this research is panel data regression, with $\mathrm{HDI}$ as local economic development indicator as dependent variable. HDI stated that the basis of human development is the opportunity for the welfare of life and health, the acquisition of knowledge as an effort to get equal opportunities, and access to essential resources to obtain a normal way of life and become part of society. These values are in line with the understanding of Local Economic Development as an indicator in determining the approach to economic development. (Madudova \& Palencikova, 2019) Proportion of creative workers, Proportion of higher education graduates, Electrification ratio, Accessibility Ratio also Internet Ratio as independent variable.

\section{Regresion model equation}

$$
\begin{gathered}
L E D_{\text {it }}=\beta_{0}+\beta_{1} P C W_{\text {it }}+\beta_{2} P G R A D_{\text {it }}+\beta_{3} E L E C T_{\text {it }} \\
+\beta_{4} A C C E S_{\text {it }}+\beta_{5} I N E T_{\text {it }}+\mu_{\text {it }}
\end{gathered}
$$

where LED it is local economy development represent from HDI, PCW is proportion of creative workers, PGRAD is proportion of higher education graduates, ELECT is electrification ratio, ACCES is accessibility ratio and INET is internet ratio.

\section{Result And Discussion}

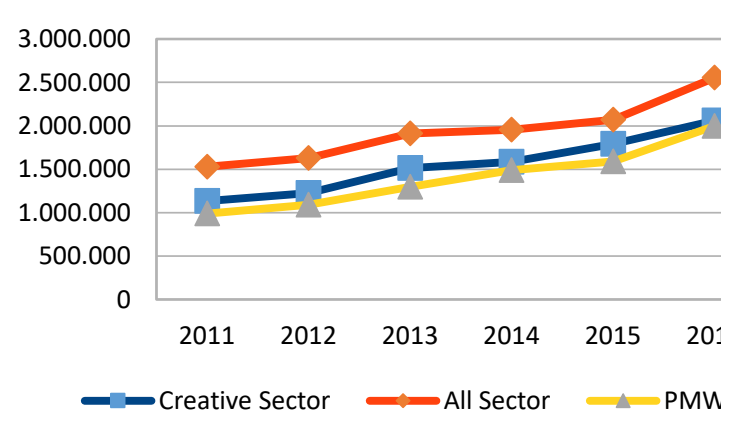

Figure 2 Average Wages per Month for the Creative Economy Sector, 2011-2016

Source:(Badan Ekonomi Kreatif, 2017)

Creative economy is an economic concept based on new ideas that refer to creativity and information. Indicators of human creativity are used as a factor of production in driving the economy. So that in essence the creative economy puts forward ideas and innovations 
that can make a positive contribution to improving the economy. The creative economy based on Kementerian Pariwisata dan Ekonomi Kreatif, (2014) views that the creative economy is a transformation of the production structure in the context of production factors. Where the initial conditions for a developing economy were based on human and natural resources, which in turn continued to develop and made ideas one of the factors of production so that the economy received significant added value.

Based on the wages received by workers in the creative economy sector, on average, they are above the Provincial Minimum Wage (PMW). In 2016 the average wages per month for the Creative Economy sector were 2,059,899, above the average wages for all sectors and the PMW of $1,997,819$ as well as in previous years. This indicates that the creative economy sector has a positive contribution to increasing people's income. This will have a positive impact on the welfare of the community.

Table 1. Descriptive Statistic Results

\begin{tabular}{cccccc}
\hline Variable & Obs & Mean & Min & Max & $\begin{array}{c}\text { Std. } \\
\text { Dev }\end{array}$ \\
\hline LED & 155 & $\begin{array}{c}67.791 \\
23\end{array}$ & 55.01 & 78.99 & 4.143 \\
& & 9.0294 & 1.544 & 21.40 & 5.009 \\
PCW & 155 & 22 & 132 & 716 & 066 \\
& & 32886 & .0266 & 2.233 & .3704 \\
PGRAD & 155 & 92 & 842 & 252 & 838 \\
& & 78.052 & 29.25 & 100 & 12.16 \\
ELCT & 155 & 84 & 4.967 & 1068. & 177.3 \\
ACCES & 155 & 77.449 & 7637 & 357 & 031 \\
& & 76 & 777 & \\
INET & 155 & 15.544 & 4.12 & 46.63 & 7.442 \\
\hline \multicolumn{5}{c}{ Source: author calculation }
\end{tabular}

Based on table 1 shows descriptive statistics of 155 observation which is 31 province and 5 years periods. The Local Economic Development (LED) shows average 67.79123, with highest score on DKI Jakarta province as 78.99 and the lowest score on Papua Province 55.01. The average Proportion Creative Worker (PCW) 9.029422 percent, with highest 21.40716 percent on DKI Jakarta province and the lowest 1.544132 on Papua province. The average Proportion High Education Graduate (PGRAD) 0,3288692 , with highest proportion on DKI Jakarta Province as 2.233252 and the lowest on Bali Province. The electricity ratio (ELECT) average 78.05284 with highest ratio on DKI Jakarta Province as 100 and the lowest ratio on Papua Province as 29.25 . The accessibility ratio average 77.44976 with the highest ratio on DKI Jakarta 1068.357 and the lowest Papua Province 4.967777. Meanwhile the average Faculty of Economics and Business, Brawijaya University internet coverage ratio as 15.54413 with highest ratio on DKI Jakarta Province and the lowest ratio South East Nusa.

\subsection{Model Analysis}

The reason using of panel data according to Baltagi in Gujarati \& Porter, (2010) has the following advantages such as (1) Panel data estimation technique can take into account the heterogeneity explicitly in the calculation by involving the specific subject variable; (2) By combining time-series and cross-sectional observations, panel data can provide more informative data, more variability, less collinearity between variables, higher degrees of freedom and more efficiency; (3) Panel data is perfect for studying dynamic changes; and (4) Panel data are better at detecting and measuring effects that cannot be observed in pure crosssectional or time series data.

As the panel regression method has 3 models, namely the Common Effect Model (CEM) or pool, Fixed Effect Model (FEM), and Random Effect Model (REM). Based on these 3 models, a suitable research model will be determined in this study. The several test is carried out to choose the fixed effect or random effect method. The following are the results of the test.

Table 2. Best Model Result Test

\begin{tabular}{ccc}
\hline Test & Value & Result \\
\hline Chow Test & 0.00000 & FEM \\
Haussman & 0.08093 & REM \\
Test & 0.0000 & REM \\
LM Test & \multicolumn{2}{c}{ Source: author's calculation }
\end{tabular}

The Likelihood Ratio-Chow Test is used to find a method between the common effect model (CEM) approach and the fixed effect model (FEM). If there is rejection, Ho can use the chisquare probability statistical considerations. Ho is rejected and $\mathrm{Ha}$ is accepted when prob $<0.05$, which means that the model is suitable for use in regression, namely the fixed effect model. According table 2 best fit model for this study is Fixed Effect Model.

The choice of a suitable model based on the results of the Chow Test is the Fixed Effect Model, so the Hausman Test must be carried out as the next step to find the best model. The results of the Hausman Test regression above, it can be seen that the chi-square probability value is $0.08093>0.05$, which means that $\mathrm{Ho}$ is accepted and $\mathrm{Ha}$ is rejected. Based on the Hausman Test, the appropriate model for this study is the Random Effect Model. After carrying out the Hausman Test and the results obtained 
are the Random Effect Model, then the next test must be carried out, namely the Lagrange Multiplier Test.

Based on the results of the regression analysis on table 2 , it can be seen that the Pvalue of Breusch Pagan LM in this model is $0.0000<0.05$, meaning that $\mathrm{Ho}$ is rejected and $\mathrm{Ha}$ is accepted. The model most suitable for use in this study is the Random Effect Model. The Lagrange Multiplier test is the last test that must be done to get the best model in research using panel data, so the results of this test will be used in this study. After thorough testing, it can be seen that the best model selection in this study is the Random Effect Model.

Table 3. Random Effect Model

\begin{tabular}{ccccc}
\hline Variable & Coef. & $\begin{array}{c}\text { Std. } \\
\text { Error }\end{array}$ & $\begin{array}{c}\text { z- } \\
\text { Statist } \\
\text { ic }\end{array}$ & Prob. \\
PCW & .1375339 & .0476142 & 2.89 & $0.004^{\star}$ \\
PGRAD & 1.232869 & .4670927 & 2.64 & $0.008^{\star}$ \\
ELECT & .0292922 & .0054191 & 5.41 & $0.061^{* *}$ \\
ACCES & .0032537 & .0017355 & 1.87 & $0.000^{*}$ \\
& & & & \\
INET & .1783 & .0130 & 13.6 & 0.000 \\
& 338 & 536 & 6 & $*$ \\
Cons & 60.83 & .5494 & 110. & 0.000 \\
& 354 & 081 & 73 & $*$ \\
\hline R-Squared Adjusted & 0.7335 & $\begin{array}{c}\text { Prop }> \\
\text { chi2 }\end{array}$ & 0.0000 \\
R-Squared & \multicolumn{5}{c}{0.7324} \\
\hline \multicolumn{5}{c}{ Source: author calculation } \\
\hline
\end{tabular}

Based on Table 3 the coefficient of determination shows a value of $\mathrm{R}$-squared is 0.7324 . This means that the independent variables in this study (PCW, PGRAD, ELECT, and INET) can explain dependent variable (PEL) of $73.24 \%$, the rest is explained by variables outside this research model. Moreover the obtained $p$-value from simultaneous testing is 0.0000 , which means $p$-value $<\alpha=0,05$. So it can be concluded that all independent variable in simultaneously have significant effect towards dependent variable.

To see the effect of each independent variable partially on the dependent variable using the t-test. The basis for determining this test is to compare the probability value of each variable to the value $\alpha=0.05$. So that in this test the following results are obtained. The variable of the Proportion of Creative Worker has a value of Probs | z | 0.004 with a coefficient of 0.1375339 . So that the PCW variable shows a significant influence relationship with a positive Faculty of Economics and Business, Brawijaya University direction on the dependent variable on the Local Economic Development Index

The Proportion of University Graduates variable has a value of $P$ rob $>|z| 0.008$ with a coefficient of 1.232869. So that the PGRAD variable shows the relationship has a significant effect on the dependent variable on the Local Economic Development. Same as Electrification Ratio variable has a value of Probs | z | 0.000 with a coefficient of 0.0292922 . So that the ELECT variable shows the relationship has a significant effect on the dependent variable Local Economic Development. And also The internet Coverage Ratio variable has a value of Prob $>\mid z$ 0.000 with a coefficient of 0.1783338 . So that the INET variable shows a significant influence relationship with a positive direction on the dependent variable on the Local Economic Development.

Only Accessibility Ratio variable has a value of Prob $>$ | z | 0.061 with a coefficient of 0.0032537 . So that the ACCES variable shows that the relationship does not have a significant effect on the dependent variable on the Local Economic Development.

From testing these parameters, the equation can be written as follows:

$$
\begin{gathered}
L E D_{\mathrm{it}}=60.83354+0.1375339 P C W_{\mathrm{it}} \\
+1.232869 P G R A D_{\mathrm{it}} \\
+0.292922 E L E C T_{\mathrm{it}}+0.0032537 A C C E S_{\mathrm{it}} \\
+0.1783338 I N E T_{\mathrm{it}}
\end{gathered}
$$

\subsection{Discussion}

The Local Economic Development Index is proxied using the Human Development Index. The index chosen represents 3 principles of Local Economic Development in the form of Living Standards, Equality, and Sustainability (Blakely \& Leigh, 2013) . It is known that the creative economy variable in this case the Creative Economy workforce has a significant influence on the local economic development index.

In this case, the creative working class or those projected in the creative workforce has a positive contribution to increase local economic development. The creative working class is considered to be able to encourage ideas and innovation in an area which will certainly bring economic improvement in that region. The high concentration of the creative working class will certainly have a positive impact on economic development.

This is similar with Avilés-Ochoa \& Canizalez-Ramírez, (2015); Awalia, Mulatsih, \& 
Priyarsono, (2013); Fahmi \& Koster, (2017); Tao et al., (2019) which states that a creative workforce has a positive impact on economic and regional growth. The creative workforce is seen as one of the accelerating factors in improving the economy. Boschma \& Fritsch, (2009) suggests that the high concentration of creative working class in a region has a tendency to increase the standard of living in that region.

Judging from the average wages earned from the creative economy sector, it tends to be greater than the PMW. This shows that the creative economy sector has the potential to increase living standards for the creative working class which will have a positive impact on local economic development.

The variable proportion of university graduates is seen as important in improving the creative economy. Given the contribution of college graduates is often positive for the creative economy. It can be identified that the creative workforce often requires high work skills (Fahmi \& Koster, 2017). The importance of higher education levels in supporting the creative economy also encourages equality in getting opportunities to improve their welfare.

The other independent variables related to other creative economy variables are internet coverage variables which have a significant effect on the dependent variable of local economic development. This shows that connectivity in local economic development is very necessary and has a positive impact on local economic development. This finding similar with Fahmi \& Koster, (2017); Tao et al., (2019) research. Same as Hidayat, Prasetya, \& Wulandari, (2021) finding that internet coverage can be positive impact to reducing poverty with providing adequate information that makes more knowledgeable and informative.

The electrification ratio has a significant effect on the dependent variable. This is reasonable considering the need for electricity in the economic sector is inevitable. Apart from being one of the supporting factors in improving the quality of life, it also encourages the economy to run more optimally. Electrification has become a part of life for economic development to a better level.

Meanwhile, accessibility does not have a significant effect on local economic development. Similar with Pavel, Moldovan, Neamtu, \& Hintea, (2018); Pavel \& Moldovan, (2019) research that basic infrastructure has a negative effect on local economic development. This happens because infrastructure projects have not been able to provide facilities for basic services. Another condition is that the infrastructure project only targets certain areas, especially suburban areas, so that the impact on local economic development is minimal.

The proportion of higher education graduates has a significant impact on local economic development. This is in line with research Fahmi \& Koster, (2017) that higher education graduates play a role in increasing economic development and supporting the increase in the creative economy in a region. As a catalyst in the economic development of higher education graduates, it is human capital that needs to be developed even better.

\section{Conclusion}

Based on the results of research above it can be concluded that creative economy, in this case creative workforce, has a significant influence on local economic development. A creative workforce has a positive influence on local economic development. This is evidenced by the income of the creative working class which is above the average PMW. So that it will make a positive contribution to increasing local economic development. As the high concentration of creative workers in an area will have a positive impact on that area.

Supporting factors for the creative economy, such as the proportion of higher education graduates, the electrification ratio, and internet coverage have a significant effect. Only the accessibility ratio has insignificant influence on local economic development. Higher education graduates are considered to be the driving force for the creation of a creative economy in a region. The higher the proportion of graduates is expected to encourage the creation of an increasing creative economy and become a driving force for local economic development. Electrification is a basic infrastructure that must be fulfilled, not only in increasing the development of the creative economy but in the context of developing the local economy. Accessibility is needed in economic development, but there is a need for consideration in the placement of road access within the region in order to facilitate access and smooth the flow of the economy in an area.

There is a need for a creative workforce policy so that it is not concentrated in advanced areas. One policy that can be done is to make it attractive to areas that have little creative workforce. This policy is considered very important considering the even condition of competent human resources in Indonesia which tends to be centered on the island of Java. 
Basically, the supporting factors for the creative economy have been fulfilled, but there needs to be an increase in terms of the impact of this infrastructure for local economic development. Comprehensive policies are needed in the development of physical and human capital in order to create synergies for economic development.

In this study, there are several limitations, the data used on has limited availability in the 20112015 time frame and there are 3 provinces that do not have complete data. The calculation of the local economic development index uses the human development index approach as an indicator of local economic development.

\section{REFERENCES}

Avilés-Ochoa, E., \& Canizalez-Ramírez, P. M. (2015). Cultural industries and economic growth. A model to study the emergence of creative clusters. Economía, Sociedad y Territorio, 15(47), 185-216. Retrieved from

http://www.redalyc.org/pdf/111/1113281 6008.pdf

Awalia, N. R., Mulatsih, S., \& Priyarsono, D. S. (2013). Analisis Pertumbuhan Teknologi, Produk Domestik Bruto, Dan Ekspor Sektor Industri Kreatif Indonesia. Jurnal Ekonomi Dan Kebijakan Pembangunan, 2(2), 135-155.

https://doi.org/10.29244/jekp.2.2.135-155

Badan Ekonomi Kreatif. (2017). UPAH TENAGA KERJA EKONOMI KREATIF 2011-2016. Jakarta.

Bakhshi, H., McVittie, E., \& Simmie, J. (2008). Creating Innovation: Do the creative industries support innovation in the wider economy? Nesta London.

Bekraf-BPS. (2018). Data Statistik dan Hasil Survey Ekonomi Kreatif 2016. Retrieved from www.bekraf.go.id

Blakely, E. J., \& Leigh, N. G. (2013). Planning Local Economic Development. SAGE Publications. Retrieved from https://books.google.co.id/books?id=XGO spT2j_WoC

Boccella, N., \& Salerno, I. (2016). Creative Economy, Cultural Industries and Local

Faculty of Economics and Business, Brawijaya University
Development败. Procedia - Social and

Behavioral Sciences, 223, 291-296.

https://doi.org/10.1016/j.sbspro.2016.05.3 70

Boschma, R. A., \& Fritsch, M. (2009). Creative Class and Regional Growth : Countries. Economic Geography, 85(4), 391-423.

Fahmi, F. Z., \& Koster, S. (2017). Creative Industries and Regional Productivity Growth in the Developing Economy: Evidence from Indonesia. Growth and Change, 48(4), 805-830. https://doi.org/10.1111/grow.12212

Goga, S., Murphy, F., \& Swinburn, G. (2006). Local economic development: a primer developing and implementing local economic development strategies and action plans, 91 .

Gujarati, D. N., \& Porter, D. C. (2010). Essentials of Econometrics. McGraw-Hill Irwin.

Howkin, J. (2001). The Creative Economy. London: Penguin Book.

Innocenti, N., \& Lazzeretti, L. (2019). Do the creative industries support growth and innovation in the wider economy? Industry relatedness and employment growth in Italy. Industry and Innovation, 26(10), 1152-1173.

https://doi.org/10.1080/13662716.2018.15 61360

Kementerian Pariwisata dan Ekonomi Kreatif. (2014). Kekuatan Baru Indonesia Menuju 2025. Jakarta: Kementerian Pariwisata dan Ekonomi Kreatif RI.

Madudova, E., \& Palencikova, Z. (2019). CREATIVE ACTIVITIES VALUATION USING A TOPSIS - BASED DECISION SUPPORT ALGORITHM. Facta Universitatis. Series: Economics and Organization, 377-387. https://doi.org/10.22190/fueo1904377m

Ochoa, E. A., \& Ramírez, P. M. C. (2018). Cultural industries and spatial economic growth a model for the emergence of the 
creative cluster in the architecture of Toronto. City, Culture and Society, 14, 47-55.

https://doi.org/10.1016/j.ccs.2018.03.001

Palavicini-Corona, E. I. (2012). Local Economic Development in Mexico: The Contribution of the Bottom-Up Approach. London School of Economics and Political Science.

Pavel, A., Moldovan, B., Neamtu, B., \& Hintea, C. (2018). Are investments in basic infrastructure the magic wand to boost the local economy of rural communities from Romania? Sustainability (Switzerland), 10(10) https://doi.org/10.3390/su10103384

Pavel, A., \& Moldovan, O. (2019). Determining local economic development in the rural areas of Romania. Exploring the role of exogenous factors. Sustainability (Switzerland), 11(2). https://doi.org/10.3390/su11010282

Power, D., \& Nielsén, T. (2011). Priority Sector Report: Creative and Cultural Industries. Innova. Stockholm: European Cluster Observatory. Retrieved from http://www.clusterobservatory.eu/common /galleries/downloads/CreativeAndCulturall ndustries.pdf

Rahma, H. (2006). Pengembangan Ekonomi Lokal. Jurnal Kebijakan Ekonomi, 1(3), 303-327.

Rahma, H. (2012). Acuan Penerapan Pengembangan Ekonomi Lokal untuk Kota dan Kabupaten. Jakarta: Direktorat Jenderal Cipta Karya, Kementerian Pekerjaan Umum.

Romer, P. (1997). The origins of endogenous growth. A Macroeconomics Reader, 8(1), 3-22. https://doi.org/10.4324/9780203443965.ch 26

Schumpeter, J. A. (1994). Capitalism, Socialism and Democracy. Routledge (5th ed.). London.
Simms, A., Freshwater, D., \& Ward, J. (2014). The Rural Economic Capacity Index (RECI): A Benchmarking Tool to Support Community-Based Economic Development. Economic Development Quarterly, 28(4), 351-363. https://doi.org/10.1177/089124241351267 2

Supriyadi R, E. (2007). Telaah Kendala Penerapan Pengembangan Ekonomi Lokal: Pragmatisme Dalam Praktek Pendekatan Pel. Journal of Regional and City Planning.

Tao, J., Ho, C.-Y., Luo, S., \& Sheng, Y. (2019). Agglomeration economies in creative industries. Regional Science and Urban Economics, 77, 141-154. https://doi.org/10.1016/j.regsciurbeco.201 9.04 .002

UN-Habitat. (2002). Activity Report 2002 and Work Plan 2003. Japan.

Widjonarko. (2013). Evaluasi Kinerja KAPET (Kawasan Pengembangan Ekonomi Terpadu) Palapas Dalam Mendorong Pertumbuhan Ekonomi di Provinsi Sulawesi Tengah. Jurnal Pembangunan Wilayah \& Kota, 9(1), 74. https://doi.org/10.14710/pwk.v9i1.6528

Wong, C. (2002). Developing Indicators to Inform Local Economic Development in England. Urban Studies, 39(10), 18331863.

https://doi.org/10.1080/004209802200000 2984

Zhou, Y., He, C., \& Zhu, S. (2016). Does Creative Destruction Work for Chinese Regions. Growth and Change, 48(3), 274-296. https://doi.org/10.1111/grow.12168 